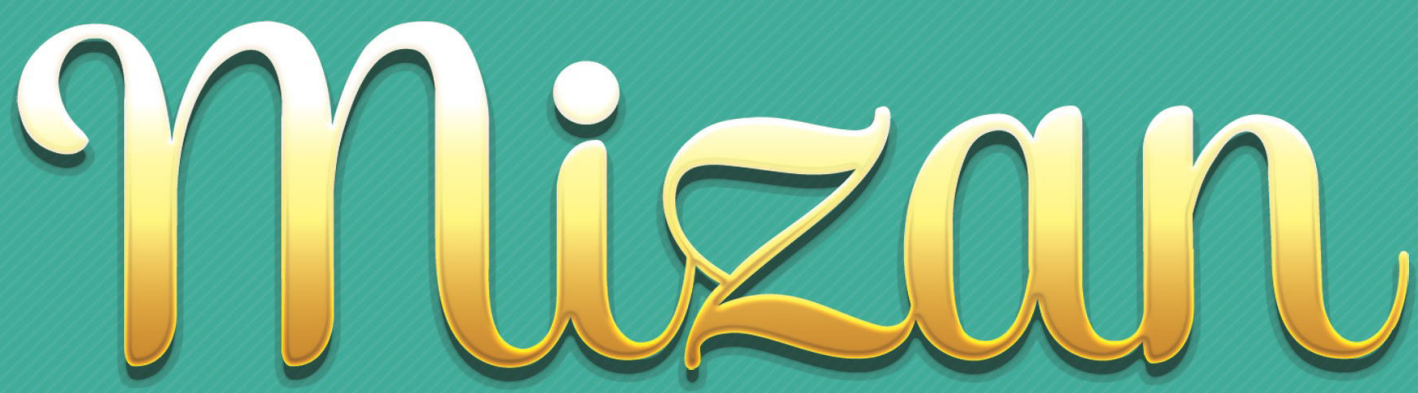

JOURNAL OF ISLAMIC LAW

Diskursus Gender Dalam Hukum Islam Mesraini

Studi Komparatif Antara Hukum Islam dan Hukum Perdata Belanda (BW)

Tentang Wali Nikah Bagi Anak Angkat

Rizky Nanda, Syarifah Gustiawati Mukri

Selisik Upaya Pencegahan Korupsi dan Gratifikasi

Di Kota Tangerang Selatan Banten

Supriyadi Ahmad, Yuniati Nuraini

Studi Komparatif Pemikiran Imam Nawawi dan Yusuf al-Qardhawi

Tentang Berjabat Tangan Dengan Bukan Mahram Dalam Islam

Dani Ahmad Ramdani, Sutisna

Ilhaq Hukum Pada Masyarakat Multi Kultur Indonesia;

Pemikiran Hukum Muhammad Hasyim Asy'ari 1871-1947 M

Qosim Arsadani AS

Makna Fii Sabilillah Sebagai Mustahiq Zakat

Perspektif Sayyid Abu Bakar Asy-Syatho dan Yusuf Qardhawi

Muhammad Hafizhuddin Hazazi, Suyud Arif, Sutisna

Transaksi Tanpa ljab Kabul

Dalam Masyarakat Perspektif Hukum Islam

Ahmad Mukri Aji

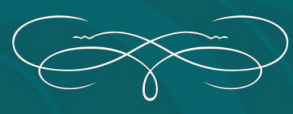

Fakultas Agama Islam

Universitas Ibn Khaldun

Bogor 


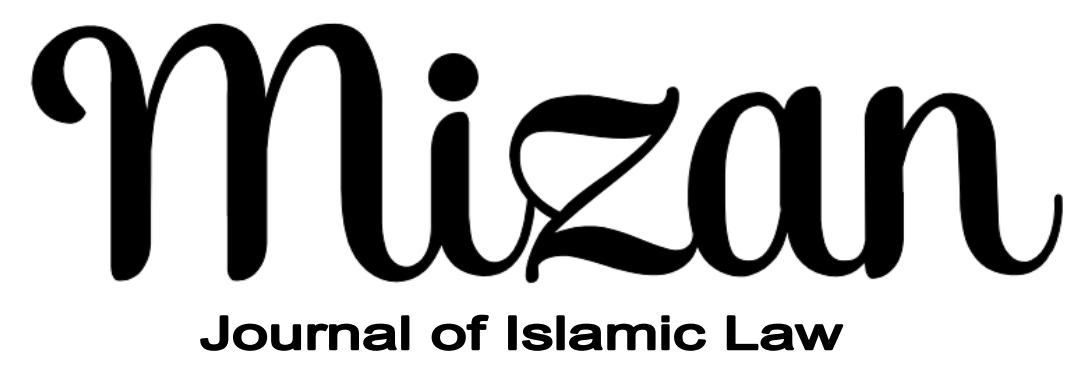

\section{VOL. 2 NO. 1 (2018)}

Mizan: Journal of Islamic Law is continuation of Mizan Ahwal Al-Syakhsiyah Journal since 2013, published by the faculty of Islamic Studies, Universitas Ibn Khaldun (UIKA) Bogor West Java, Indonesia. Mizan of Islamic Law published twice a year since 2017 (June and Desember), is a multilingual (Bahasa Indonesia, Arabic, English, and

Russian), Peer-Reviewed journal, and specialized in Islamic Law, Islamic Studies, and Sharia. This journal is published by the faculty of Islamic Studies, Universitas Ibn Khaldun Bogor, in partnership with APSI (Indonesian Sharia Advocates Association). Editors welcome scholars researchers and pratitioner of Islamic Law around the world to submit scholarly articles to be published throught this journal. All articles will be reviewed by experts before accepted for publication, each author is solely responsible for the content of published articles.

MIZAN; Journal of Islamic Law has been indexed at Google Scholar, Moraref, Sinta, and become a CrossRef Member since year 2017. Therefore, all articles published by MIZAN; Journal of Islamic Law will have unique DOI number.

[ISSN: 2598-974X, E-ISSN: 2598-6252]

\section{ADVISORY EDITORIAL BOARD}

Didin Hafidhuddin (Universitas Ibn Khaldun Bogor)

Muhammad Munir (International Islamic University Islamabad, Pakistan)

Andi Salman Maggalatung (UIN Syarif Hidayatullah Jakarta)

Ending Bahruddin (Universitas Ibn Khaldun Bogor)

Ahmad Mukri Aji (UIN Syarif Hidayatullah Jakarta)

Muhammad Kholil Nawawi (Universitas Ibn Khaldun Bogor)

Hendri Tanjung (Universitas Ibn Khaldun Bogor)

Irfan Syauqi Beik (Institut Pertanian Bogor)

Nur Rohim Y (Kazan Federal University, KFU Russia)

\section{EDITOR IN CHIEF}

Syarifah Gustiawati Mukri

$$
\begin{gathered}
\text { EDITORS } \\
\text { Suyud Arif } \\
\text { Sutisna } \\
\text { Yono }
\end{gathered}
$$

\section{ASSISTANT TO THE EDITORS}

Siti Anisaul Kamilah

\section{Redaktur Office}

Fakultas Agama Islam Universitas Ibn Khaldun Bogor Jawa Barat

Jl. KH. Sholeh Iskandar KM. 2 Kedung Badang Tanah Sareal Bogor 16162

Telp. (62-251) 8356884, Faks. (62-251) 8356884

Website: http://www.jurnalfai-uikabogor.org/index.php/mizan,

E-mail: jurnalmizan.uikabogor@gmail.com

Permalink: https://uika-bogor.academia.edu/JurnalMizanUIKABogor 


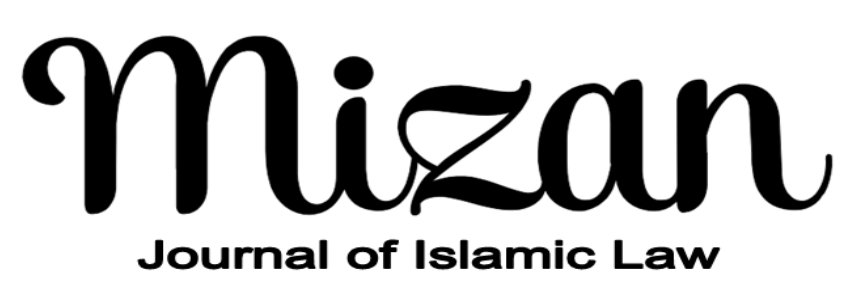

Menyambut baik kontribusi dari para ilmuwan, sarjana, profesional, dan peneliti dalam disiplin ilmu hukum untuk dipublikasi dan disebarluaskan setelah melalui mekanisme seleksi naskah, telaah mitra bebestari, dan proses penyuntingan yang ketat. 


\section{DAFTAR ISI}

1 Diskursus Gender Dalam Hukum Islam

(Gender Discourse in Islamic Law)

Mesraini

13 Studi Komparatif Antara Hukum Islam dan Hukum Perdata Belanda (BW) Tentang Wali Nikah Bagi Anak Angkat

(Comparative StudyBetween Islamic Law and Dutch Civil Law (BW) About Marriage Guardians for Adopted Children)

Rizky Nanda, Syarifah Gustiawati Mukri

29 Selisik Upaya Pencegahan Korupsi dan Gratifikasi Di Kota Tangerang Selatan Banten

(Efforts to Prevent Corruption and Gratification in South Tangerang City of Banten) Supriyadi Ahmad, Yuniati Nuraini

47 Studi Komparatif Pemikiran Imam Nawawi dan Yusuf al-Qardhawi Tentang Berjabat Tangan Dengan Bukan Mahram Dalam Islam

(Comparative Study of Imam Nawawi and Yusuf al-Qardhawi about Shaking Hands Not Mahram in Islam)

Dani Ahmad Ramdani, Sutisna

59 Ilhaq Hukum Pada Masyarakat Multi Kultur Indonesia; Pemikiran Hukum Muhammad Hasyim Asy'ari 1871-1947 M

(Ilhaq Law in Multi Culture Society of Indonesia; Legal Thought Muhammad Hasyim Asy'ari 1871-1947)

Qosim Arsadani AS

75 Makna Fii Sabilillah Sebagai Mustahiq Zakat Perspektif Sayyid Abu Bakar Asy-Syatho dan Yusuf Qardhawi

(The Meaning of Fi Sabilillah As Mustahiq Zakat Perspective Sayyid Abu Bakar AsySyatho and Yusuf Qardhawi)

Muhammad Hafizhuddin Hazazi, Suyud Arif, Sutisna

91 Transaksi Tanpa Ijab Kabul Dalam Masyarakat Perspektif Hukum Islam

(Unsolicited-Qabul Transaction in Society Perspective of Islamic Law)

Ahmad Mukri Aji 



\title{
Studi Komparatif Antara Hukum Islam dan Hukum Perdata Belanda (BW) Tentang Wali Nikah Bagi Anak Angkat ${ }^{\star}$
}

(Comparative StudyBetween Islamic Law and Dutch Civil Law (BW) About Marriage Guardians for Adopted Children)

\author{
Rizky Nanda, Syarifah Gustiawati Mukri \\ FAI Universitas Ibn Khaldun Bogor \\ J1. Sholeh Iskandar km. 02, Kedung Badak Bogor \\ E-mail: risky.nanda@gmail.com, syarifah@fai-uika.ac.id
}

DOI: https://doi.org/10.32507/mizan.v2i1.210

\begin{abstract}
:
The existence of a marriage guardian in marriage is a harmony that must be fulfilled for the prospective bride in marriage. This is as stipulated in Article $19 \mathrm{KHI}$. His father's position cannot be replaced by his position as guardian at any time. Although the biological father never gave a living or disappeared during the development period of the child. This study wants to examine the method of comparison between the rules in Islamic Law and in Civil Law (BW) on the position of the marriage guardian.
\end{abstract}

Keywords: Comparative Study, Marriage Guardian, Adopted Child, Islamic Law and Civil Law (BW)

\begin{abstract}
Abstrak:
Adanya wali nikah dalam pernikahan merupakan rukun yang harus dipenuhi bagi calon mempelai wanita dalam pernikahan. Hal ini sebagaimana diatur dalam Pasal 19 KHI. Posisi ayah kandung tidak dapat tergantikan kedudukannya sebagai wali hingga kapanpun. Meski ayah kandung tersebut tidak pernah memberi nafkah atau menghilang pada masa perkembangan sang anak. Penelitian ini ingin mengkaji dengan metode perbandingan antara aturan dalam Hukum Islam dan dalam Hukum Perdata (BW) terhadap kedudukan wali nikah tersebut.

Kata Kunci: Studi Komparatif, Wali Nikah, Anak Angkat, Hukum Islam dan Hukum Perdata (BW)
\end{abstract} Juni 2018

* Naskah diterima tanggal: 17 Maret 2018, direvisi: 25 Mei 2018, disetujui untuk terbit: 15 


\section{Pendahuluan}

Pada dasarnya Hukum Perdata yang selama ini kita kenal dan ketahui merupakan serangkaian aturan hukum yang mengatur hubungan hukum antara orang yang satu dengan yang lainnya dengan menitik beratkan kepada kepentingan perseorangan saja, yang bersumber pada Kitab Undang-Undang Hukum Perdata atau yang dikenal dengan istilah BW. Begitu juga dalam Undang-Undang Republik Indonesia Nomor 1 Tahun 1974 tentang Pernikahan dan Kompilasi Hukum Islam atau disingkat dengan (KHI) yang pada tanggal 10 Juni 1991, mendapat legalisasi pemerintah dalam bentuk Instruksi Presiden kepada Menteri Agama untuk digunakan oleh Instansi Pemerintah dan oleh masyarakat yang memerlukannya. Instruksi itu dilaksanakan dengan Keputusan Menteri Agama Nomor 154 tanggal 22 Juli 1991. Maka dengan demikian bahwa baik itu, KUH Perdata (Burgerlijk Wetboek), Undang-Undang Republik Indonesia Nomor 1 Tahun 1974 maupun Kompilasi Hukum Islam, tidak akan terlepas pembahasannya mengenai perwalian, karena definisi daripada Hukum Perdata tersebut yaitu hukum yang mengatur tentang kepentingan perseorangan dalam hal keperdataan. ${ }^{1}$

Dalam aturan Islam, anak angkat yang diasuh orang tua angkat, tidak boleh diubah nasabnya. Dulu, Rasulullah shallallahu 'alaihi wa sallam memiliki anak angkat namanya zaid. Hingga masyarakat menyebutnya Zaid bin Muhammad. Padahal Nama ayahnya yang asli: Haritsah. Sampai akhirnya Allah menurunkan ayat di atas, karena tidak ada hubungan nasab antara anak angkat dengan orang tua angkat, maka tidak berlaku hukum-hukum nasab dalam hal ini, sehingga mereka tidak bisa saling mewarisi, tidak bisa menjadi mahram, tidak pula wali nikah. Hukum nasab yang berlaku, tetap kembali ke bapaknya yang asli. Sehingga yang berhak menjadi wali untuk anak ini adalah ayah kandungnya dan keluarga ayah kandungnya. Ayah angkat bisa jadi wali jika dia mendapatkan mandat dari ayah kandungnya. Dalam hal ini, ayah angkat berstatus sebagai penerima wasiat (wakil) si bapak asli. Sebagaimana keterangan Al- Buhuti di atas.

Sementara itu, terdapat perbedaan antara hukum Islam dengan hukum perdata Belanda mengenai wali pernikahan bagi anak angkat. Hukum perdata Belanda berasal dari hukum perdata Perancis yaitu Code Napoleon yang disusun berdasarkan hukum Romawi Corpus Juris Civilis yang pada waktu itu dianggap sebagai hukum yang paling sempurna.

Kitab Undang-Undang Hukum Perdata yang aslinya berbahasa Belanda atau dikenal dengan Burgerlijk Wetboek dan biasa disingkat dengan B.W. Sebagian materi B.W. sudah dicabut berlakunya dan sudah diganti dengan Undang-Undang RI misalnya mengenai UU Pernikahan, UU Hak Tanggungan,

${ }^{1}$ Muhammad Daud Ali, dkk, Kompilasi Hukum Islam Dalam Sistem Hukum Nasional, Cet ke- 1, (Jakarta: Logos Wacana Ilmu, 1999), h. 1 
UU Kepailitan. Setelah Indonesia Merdeka berdasarkan aturan Pasal 2 aturan peralihan UUD 1945, KUHPdt. Hindia Belanda tetap dinyatakan berlaku sebelum digantikan dengan undang-undang baru berdasarkan Undang- Undang Dasar ini. BW Hindia Belanda disebut juga Kitab Undang- Undang Hukum Perdata Indonesia sebagai induk hukum perdata Indonesia. ${ }^{2}$

Dalam Staatblaad 1917 No. 129, akibat hukum dari pengangkatan anak adalah anak tersebut secara hukum memperoleh nama dari bapak angkat, dijadikan sebagai anak yang dilahirkan dari pernikahan orang tua angkat dan menjadi ahli waris orang tua angkat. Artinya, akibat pengangkatan tersebut maka terputus segala hubungan perdata, yang berpangkal pada keturunan karena kelahiran, yaitu antara orang tua kandung dan anak tersebut. ${ }^{3}$

\section{Pengertian Wali Nikah}

Secara bahasa, wali bisa berarti rasa cinta (mahabbah) dan pertolongan (nushrah), bisa juga berarti kekuasaan (sulthah) dan kekuatan (qudrah). Ini berarti, seorang wali adalah orang yang menolong atau orang yang memiliki kekuasaan. Sedangkan menurut istilah, kata "wali" mengandung pengertian orang yang menurut hukum (agama, adat) diserahi untuk mengurus kewajiban anak yatim, sebelum anak itu dewasa, pihak yang mewakilkan pengantin perempuan pada waktu menikah (yaitu yang melakukan janji nikah dengan pengantin pria).

Kata wali dalam Kamus Besar Bahasa Indonesia diartikan sebagai pengasuh pengantin perempuan ketika nikah, yaitu orang yang melakukan janji nikah dengan laki-laki. ${ }^{4}$ Perwalian dari bahasa Arab adalah Walayah atau wilayah yaitu hak yang diberikan oleh syariat yang membuat si wali mengambil dan melakukan sesuatu, kalau perlu secara paksa diluar kerelaan dan persetujuan dari orang yang diperwalikan. ${ }^{5}$ Yang dimaksud dengan wali secara umum adalah seseorang yang karena kedudukannya berwenang untuk bertindak atas nama orang lain, Sedangkan wali dalam pernikahan adalah seseorang yang bertindak atas nama mempelai perempuan dalam suatu akad nikah. ${ }^{6}$

Wali nikah adalah orang yang bertanggung jawab atas pernikahan yang dilaksanakan di bawah perwaliannya, sehingga pernikahan tidak dianggap sah apabila tidak terdapat wali nikah, yang menyerahkan mempelai wanita kepada

\footnotetext{
2 Salim HS. Pengantar Hukum Perdata Tertulis. Jakarta: Sinar Grafika, 2008, h.88.

${ }^{3}$ Hans H.M. Ter Haar, Wilbert D. Kolkman, Leon C.A. Verstappen, etc. Hukum tentang orang, hukum keluarga dan hukum waris di Belanda dan Indonesia. Bali: Pustaka Larasan. h. 3-73

4 Tim Penyusun Kamus Pusat Penelitian dan Pengembangan Bahasa, Kamus Besar Bahasa Indonesia, Jakarta: Balai Pustaka 1989, h. 1007

5 Muhammad Bagir al-Habsy, Fiqh Praktis, Bandung: mizan 2002, hlm. 56. 6 Amir Syarifuddin, Hukum Perkawinan Islam di Indonesia, Jakarta: Kencana 2006, h. 167

${ }^{6}$ Amir Syarifuddin, Hukum Perkawinan Islam di Indonesia, h.69
} 
penghulu. Berdasarkan hal tersebut, dapat disimpulkan bahwa ijab di dalam pernikahan menurut hukum Islam adalah wewenang wali semata-mata. Sehingga karena peranan wali yang mempunyai arti penting akan tetap dipertahankan apabila wanita itu tidak mempunyai wali nasab bisa digantikan kedudukannya oleh wali hakim. Dalam pernikahan, wali adalah seseorang yang bertindak atas nama mempelai perempuan dalam suatu akad nikah. Akad nikah dilakukan oleh dua pihak, yaitu pihak laki-laki yang dilakukan oleh mempelai laki-laki itu sendiri dan pihak perempuan yang dilakukan oleh walinya.

\section{Syarat-Syarat Wali Nikah}

Wali nikah bertanggung jawab atas sahnya suatu akad pernikahan, karena perwalian itu ditetapkan untuk membantu ketidak mampuan orang yang menjadi objek perwalian dalam mengekspresikan dirinya. Oleh karena itu, tidak semua orang dapat diterima menjadi wali, tetapi hendaklah orang-orang yang memenuhi persyaratan. Adapun syarat-syarat menjadi wali sebagai berikut:

Pertama; Telah dewasa atau berakal sehat. Artinya ia sudah bisa membedakan yang baik buruk, atau sudah pernah bermimpi keluar air mani, ini merupakan syarat umum bagi orang yang melakukan akad.7 Berdasarkan sabda Nabi Saw. "Diangkatnya kalam (tidak diperhitungkan secara hukum) seseorang yang tertidur sampai ia bangun, seseorang yang masih kecil sampai ia dewasa dan orang gila sampai ia sehat."

Kedua: Laki-laki. Seorang perempuan tidak boleh menjadi wali dalam pernikahan, berdasarkan hadits Nabi yang berbunyi: Dari Abu Hurairah, ia berkata, "Wanita tidak bisa menjadi wali wanita. Dan tidak bisa pula wanita menikahkan dirinya sendiri. Wanita pezina-lah yang menikahkan dirinya sendiri." (HR. Ad Daruquthni, 3: 227. Hadits ini dishahihkan oleh Syaikh Al Albani dan Syaikh Ahmad Syakir). ${ }^{8}$

Ketiga; Muslim. Orang yang tidak beragama Islam tidak sah menjadi wali atau saksi, berdasarkan firman Allah Swt Q.S Al-Imran Ayat 28:

Janganlah orang-orang mukmin mengambil orang-orang kafir menjadi wali dengan meninggalkan orang-orang mukmin. Barang siapa berbuat demikian, niscaya lepaslah ia dari pertolongan Allah, kecuali karena (siasat) memelihara diri dari sesuatu yang ditakuti dari mereka. Dan Allah memperingatkan kamu terhadap diri (siksa)-Nya. Dan hanya kepada Allah kembali(mu).

Keempat; Tidak sedang melakukan ihram, baik haji atau umrah. Hal ini berdasarkan hadist Nabi dari „Usman menurut riwayat muslim yang

7 Amir Syarifuddin, Hukum Perkawinan Islam di Indonesia, h.69

8 Ibnu Majah, Al-Hadis As-Syarif (diakses dari CD Al-hadis As-Syarif Al- Ishdar Al-Tsani, Global Islamic Software Company, 2000), h .1872. 
mengatakan. "orang yang sedang ihram tidak boleh menikahkan seseorang dan tidak boleh pula dinikahkan oleh seseorang"

Kelima; Adil dalam arti tidak pernah terlihat dengan dosa besar dan tidak sering melakukan dosa kecil serta tetap memelihara sopan santun. Bahwa keharusan wali itu adil berdasarkan sabda Nabi, dalam hadis Aisyah yang menyatakan. "tidak sah nikah kecuali bila ada wali dan dua orang saksi yang adil."9

\section{Macam-Macam Wali Nikah}

Dalam beberapa referensi hukum Islam, baik yang berbahasa Arab atau berbahasa Indonesia, ulama berbeda-beda dalam menyebutkan macam wali dalam pernikahan, maka macam-macam wali nikah yang cocok/relevan untuk daerah Indonesia yang mayoritas menggunakan mazhab Syafici sebagai landasan hukum. Adapun rinciannya sebagai berikut:

a. Wali nasab.

Wali nasab adalah wali nikah karena ada hubungan darah nasab dengan wanita yang akan melangsungkan pernikahan atau orang-orang yang terdiri dari keluarga calon mempelai wanita dan berhak menjadi wali. ${ }^{10}$

Adapun susunan urutan wali adalah sebagai berikut; 1). Bapaknya, 2). Kakeknya (Bapak dari bapak mempelai perempuan), 3). Saudara laki-laki yang seibu sebapak, 4). Saudara laki-laki yang sebapak, 5). Anak laki-laki dari saudara laki-laki yang seibu sebapak, 6). Saudara bapak yang laki-laki (paman dari pihak bapak), 7). Anak laki-laki pamannya dari pihak bapaknya.

Sekiranya wali pertama tidak ada hendaknya diambil wali yang kedua, dan jika wali kedua tidak ada hendaklah diambil wali ketiga dan begitulah seterusnya. Mengikut tertib wali, bapak hendaklah menjadi wali bagi semua perkawinan anaknya dan jika bapak tidak ada karena meninggal dunia maka hak wali berpindah kepada kakek pengantin perempuan itu dan jika kakek juga meninggal dunia maka hak wali itu berpindah kepada saudara lelaki seibusebapak kepada pengantin perempuan dan begitulah bidang kuasa wali mengikuti tertib susunannya. ${ }^{11}$

b. Wali tahkim

Yaitu wali yang diangkat oleh calon mempelai suami dan atau calon istri. Hal itu diperbolehkan, karena ada bukti wali yang berhak tidak dapat menjalankan tugasnya suatu sebab tertentu atau menolak menjadi wali. Seperti yang telah diriwayatkan oleh Yunus bin Abdil A"la, bahwa Syafiei pernah

\footnotetext{
${ }_{9}^{9}$ Amir Syarifuddin, Hukum Perkawinan Islam di Indonesia, h. 77-78.

${ }_{10}$ Slamet Abidin Dan Aminuddin, Fiqh Munakahat 1, Bandung: Pustaka Setia 1999, hlm.24

11 Tihami Sohari Sahrani, Fiqh Munakahat (Kajian Fikih Nikah Lengkap), Jakarta: Raja Grafindo Persada, 2009, h. 89
} 
berkata "seandainya ada seorang perempuan dalam suatu perkumpulan, ia memasrahkan wali kepada seorang laki-laki, sedang perempuan tersebut tidak mempunyai wali, maka hal tersebut dianggap boleh dilakukan, ada pula yang mengemukakan, bahwa wali nikah dapat diangkat dari orang yang terpandang, disegani, luas ilmu fikihnya terutama tentang munakahat. ${ }^{12}$

c. Wali Mujbir

Adapun yang dimaksud dengan wali mujbir adalah seorang wali yang berhak mengawinkan tanpa menunggu kerelaan yang dikawinkan itu. ${ }^{13}$ Disebabkan pertimbangan kemaslahatan tetapi dapat mencegah pernikahan putrinya dengan calon pilihannya. Umpamanya mempunyai cacat, baik lahir maupun akhlak, cacat moral, sehingga dikhawatirkan akan berakibat buruk terhadap pernikahannya nanti, dan hilangnya kemaslahatan baginya. ${ }^{14}$ Padahal kemaslahatan merupakan hal yang urgen dan harus dicapai dalam segala tindakan manusia. Sehingga tercapai tujuan dari syariat itu sendiri, yaitu mencapai kemaslahatan umum bagi semua. ${ }^{15}$

\section{d. Wali Hakim}

Adapun yang dimaksud dengan wali hakim adalah penguasa atau orang yang ditunjuk oleh penguasa (pemerintah aparat KUA dan PPN) untuk menangani hal-hal yang berkaitan dengan pernikahan. Adapun seorang yang berhak menjadi wali hakim antara lain: Pemerintah (shultan), Khalifah (pemimpin) dan penguasa diberi wewenang dari kepala negara untuk menikahkan wanita yang tidak berwali.

Berdasarkan sabda Nabi Saw yang berbunyi "maka hakimlah yang bertindak menjadi wali bagi seseorang yang tidak ada walinya". ${ }^{16}$ Bahwa adanya wali hakim disebabkan karena terjadinya hal- hal sebagai berikut seperti; tidak adanya wali nasab, tidak cukup syarat-syaratnya, wali aqrab dipenjara tidak bisa ditemui, wali aqrab mempersulit, dan wali aqrabnya sedang ihram/haji. Tetapi wali hakim tidak berhak menikahkan apabila seperti wanita yang belum baligh, kedua belah pihak tidak sekufu, tanpa seizin wanita yang akan menikah, dan di luar daerah kekuasaannya. ${ }^{17}$

${ }^{12}$ Moh. Idris Ramulyo, Tinjauan Beberapa Pasal Undang-Undang No 1 Tahun 1974, Dari Segi Hukum Perkawinan Islam (JakartaInd- Hillco,1985), h. 177

${ }^{13}$ Rahmad Hakim, Hukum Perkawinan Islam, Bandung: Pustaka Setia, 2000, h.21

${ }^{14}$ Abdul Rahmad Ghazali, Fikih Munakahat, Jakarta: Kencana, 2008, h.63

15 Ahmad Mukri Aji, Urgensi maslahat mursalah dalam dialektika pemikiran hukum Islam, (Bogor: Pustaka Pena Ilahi, 2012), h. 88.

16 Beni Ahmad Saebani, Fiqh Munakahat 1, h. 249.

${ }^{17}$ Abdul Rahmad Ghazali, Fikih Munakahat, Jakarta: Kencana, 2008, h. 63. 


\section{Fungsi Wali dalam Pernikahan}

Dari beberapa rukun dalam pernikahan menurut hukum Islam, wali nikah adalah hal yang sangat penting dan menentukan, bahkan menurut Syafi i tidak sah nikah tanpa adanya wali bagi pihak perempuan sedangkan untuk pihak laki-laki tidak diperlukan adanya wali nikah. Pendapat lain mengatakan bahwa fungsi wali nikah sebenarnya adalah sebagai wakil dari perempuan, sebenarnya wali tersebut tidak diperlukan apabila yang mengucapkan ikrar ijab adalah laki-laki. Namun dalam praktik selalu pihak perempuan yang mengucapkan ijab (penawaran) sedangkan pengantin laki-laki mengucapkan ikrar qabul (penerimaan), karena pada dasarnya wanita itu pemalu maka pengucapan ijab tersebut diwakilkan pada walinya, jadi wali di sini hanya sekedar sebagai wakil karena yang paling berhak adalah perempuan tersebut. ${ }^{18}$

Pendapat di atas menjelaskan bahwa fungsi wali adalah sebagai pengganti dari perempuan yang akan melangsungkan akad nikah, akan tetapi yang berlaku pada masyarakat di jazirah Arab pada waktu awal Islam, wali dapat menikahkan anak perempuannya tanpa melalui izin anak perempuan yang akan dinikahkan, ketika Islam datang praktik menikahkan tanpa persetujuan dari anak perempuan kemudian dilarang oleh Nabi Muhammad. ${ }^{19}$

\section{Pengertian Anak Angkat}

Anak angkat dalam bahasa Inggris adoption (adopt) yang berarti anak, mengangkat anak. Kata adopsi sendiri dari kata adoptie dalam bahasa Belanda, yang punya arti mengangkat anak Dalam bahasa Arab disebut "tabanni" yang diartikan 'ittikhadzhu ibnan (اتخ ذابنا (yang menjadikannya sebagai anak). ${ }^{20}$

Menurut Soerjono Soekanto adopsi adalah suatu perbuatan mengangkat anak untuk dijadikan anak sendiri atau mengangkat seseorang dalam kedudukan tertentu yang menyebabkan timbulnya hubungan yang seolah-olah didasarkan pada faktor hubungan darah. ${ }^{21}$ Zakiyah Darajat juga mendefinisikan anak angkat (tabanni) dalam dua pengertian antara lain:

1. Seseorang yang memelihara anak orang lain yang kurang mampu untuk mendidik dan disekolahkan pada pendidikan formal. Orang itu memberi biaya pemeliharaan dan pendidikan sehingga anak itu nantinya menjadi orang yang berpendidikan dan beragama. Pengangkatan seperti itu adalah kebaikan dan Islam mengerjakan hal seperti itu.

\footnotetext{
${ }^{18}$ Beni Ahmad Saebani, Fiqh Munakahat 1, h. 250

${ }^{19}$ Mohd. Idris Ramulyo, Tinjauan Beberapa Pasal Undang-Undang No 1 Tahun 1974, Dari Segi Hukum Perkawinan Islam, Jakarta Ind-Hillco, 1985, h. 217.

${ }^{20}$ Asad M Al Kalali. Kamus Indonesia Arab, Jakarta: Bulan Bintang, 1987, h.5

${ }^{21}$ Soerjono Soekanto, Intisari Hukum Keluarga, Alumni Bandung, 2010, h. 52
} 
2. Mengangkat anak menurut adat kebiasaan yang disebut tabanni atau adopsi. Yakni anak itu dimasukkan dalam keluarga yang mengangkat sebagai anaknya sendiri sehingga menjadi ahli waris. Dari pengertian di atas disimpulkan bahwa pengangkat anak metode pangasuhan anak yang berbeda, yaitu bukan dari orang tua kandung tapi berpindah pada orang lain, yaitu orang tua angkat. Pengangkat anak dalam Islam tidak memutuskan hubungan nasab atau darah. Pengangkatan anak yang dibenarkan sesuai agama masing-masing. ${ }^{22}$

\section{Tata Cara Pengangkatan Anak}

a. Pendapat Majelis Ulama yang dituangkan dalam surat nomor: 11335/MUI/VI/82 tanggal, 18 Sya'ban 1402 H/ 10 Juni 1982 yang di tandatangani oleh ketua umum K.H. M Syukeri Ghozali, sebagai berikut. ${ }^{23}$

1) Adopsi yang tujuan pemeliharaan, penberian bantuan dan lainlain yang sifatnya untuk kepentingan anak angkat dimaksud adalah boleh saja menurut hukum Isslam.

2) Anak-anak yang beragama Islam hendaknya dijadikan anak angkat (adopsi) oleh ayah/ ibu angkat yang beragama Islam pula. Agar keIslamannya itu ada jaminan tetap dipelihara.

3) Pengangkatan anak angkat (adopsi) tidak akan mengakibatkan hak kekeluargaan yang biasa dicapai dengan nasab keturunan. Oleh karena itu adopsi tidak mengakibatkan hak waris/wali mewalikan/ mewakili, dan lain-lain. Oleh karena itu ayah ibu angkat jika akan memberikan apaapa kepada anak angkatnya hendaklah dilakukan pada masa masih sama-sama hidup sebagai hibah biasa.

4) Adapun adopsi yang dilarang adalah: a) Adopsi oleh orang-orang yang berbeda agama, misalnya Nasrani dengan maksud anak angkatnya dijadikan pemeluk agama Nasrani, bahkan sedapat-dapatnya dijadikan pemimpin agama itu.

5) Pengangkatan anak angkat Indonesia oleh orang-orang Eropa dan Amerika atau lain-lainnya biasanya berlatar belakang seperti tersebut di atas, oleh karena itu hal ini ada usaha untuk menutup adopsi.

b. Ketentuan lain diatur dalam UU RI nomor: 23 tahun. 2002. Tentang perlindungan anak. Pada bagian kedua tentang pengangkatan anak yaitu pasal 39 yang berisi: ${ }^{24}$

\footnotetext{
22 Zakiyah Darajat, Ilmu Figh, Jilid III, Yogyakarta: Dana Bhakti Wakaf, 1995, h. 145.

${ }^{23}$ Muderis Zaim, Fatwa MUI. 1982. h. 57

${ }^{24}$ Indonesia Legal Center Publising, Undang-undang RI no. 3 th. 1997 tentang, Pendidikan Anak, PT Abadi, Jakarta, 2004, h.60
} 
1) Pengangkatan anak hanya dapat dilakukan untuk kepentingan yang terbaik bagi anak dan di lakukan berdasarkan adat kebiasaan setempat dan ketentuan peraturan perundang- undangan yang berlaku.

2) Pengangkatan anak sebagaimana dimaksud dalam ayat (1), tidak membahas hubungan darah antara anak yang diangkat dengan orang tua kandungnya.

3) Calon orang tua angkat harus seagama dengan agama yang dianut oleh calon anak angkat.

4) Pengangkatan anak oleh warga negara asing hanya dapat dilakukan sebagai upaya terakhir.

5) Dalam hal asal- usul anak tidak diketahui, maka agama anak disesuaikan dengan agama mayoritas penduduk setempat. Pasal 40, juga mengatur tentang orang tua angkat yang harus dilakukan yaitu: a. Orang tua angkat wajib memberitahukan kepada anak angkatnya mengenai asal usulnya dan orang tua kandungnya. b. Pemberitahuan asal-usul dan orang tua kandungnya sebagaimana di maksud dalam ayat (1) dilakukan dengan memperhatikan kesiapan anak yang bersangkutan.

\section{Kedudukan Wali Nikah bagi Anak Angkat ditinjau dari Hukum Islam dan Hukum Perdata (BW).}

Menurut Hukum Islam anak angkat tidak dijadikan sebagai anak kandung tetapi hanya bersifat pengasuhan saja, tidak memutuskan hubungan dengan orang tua kandungnya, orang tua angkat tidak menjadi wali anak angkat tetapi setelah adanya Kompilasi Hukum Islam hak dan kewajiban serta kekuasaan orang tua ikut beralih dari orang tua kandung kepada orang tua angkat. Dalam hal perwalian orang tua angkat dapat menjadi wali atas diri anak dan harta anak angkat tetapi tidak dapat menjadi wali nikah apabila anak angkat tersebut perempuan. Akan tetapi, ayah angkat dapat jadi wali nikah, jika dia mendapatkan mandat dari ayah kandungnya. Dalam hal ini, ayah angkat berstatus sebagai penerima wasiat (wakil) si bapak asli. Namun jika bapak angkat tidak mendapatkan mandat atau tidak izin kepada wali yang sah maka dia tidak boleh menjadi wali pernikahan anak angkatnya. Jika tetap dinikahkan maka nikahnya batal.

Ditinjau dari Hukum Perdata Barat (BW). Menurut catatan Ter Haar, sebagaimana dikutip oleh J. Satrio, pengangkatan anak di dalam Hukum Adat bukan merupakan sesuatu lembaga yang asing. Lembaga ini dikenal luas hampir di seluruh Indonesia. Alasan yang menjadi pertimbangan pengangkatan anak juga bermacam-macam. Ada yang karena untuk kepentingan pemeliharaan di hari tua dan ada yang kerana kasihan terhadap anak yatim piatu. Bahkan, ada kalanya pengangkatan anak dilakukan dengan pertimbangan yang mirip dengan 
adopsi yang diatur oleh ketentuan adopsi (Stb Nomor 129 tahun 1917) yaitu untuk menghindari punahnya suatu keluarga. Tentang siapa yang boleh mengangkat anak tidak ada ketentuannya. Akan tetapi menurut R. Soeroso, dijumpai ketentuan minimal berbeda 15 tahun. Demikian juga tentang siapa yang boleh diadopsi juga tidak ada ketentuan harus anak laki-atau anak perempuan. Batas usia anak yang dapat diangkat juga berbeda antara daerah hukum yang satu dengan daerah hukum yang lain.

Hal ini wajar mengingat perbedaan-perbedaan adat di suatu tempat juga memungkinkan terjadinya perbedaan nilai-nilai hukum mereka. Walaupun tetap hukum yang berlaku merupakan kemauan dan kesepakatan dari masyarakat itu sendiri, karena hukum untuk masyarakat bukan masyarakat untuk hukum. ${ }^{25}$ Dalam hukum adat anak angkat atau pengangkatan anak ini diakui dan harus dilakukan secara jelas, tegas dan terang atau tunai, yaitu dilakukan dengan upacara-upacara adat. Hal ini berkaitan dengan hubungan atau kedudukan hukum antara anak angkat dengan orang tua angkat serta orang tua kandungnya. Dalam masyarakat hukum adat, dengan pengangkatan anak, maka putuslah hubungan keluarga antara anak tersebut dengan orang tua kandungnya. Dalam hal pewarisan anak tersebut mewarisi dari orang tua angkatnya seperti halnya anak kandung. Jadi kedudukan hukum antara anak angkat dengan anak kandung sama dalam hal pewarisan. Ketentuan yang berkaitan dengan pengangkatan anak versi Hukum Barat ini diatur dalam Staatsblad Pasal 5 s.d. 15 antara lain:

1) Suami istri atau duda yang tidak mempunyai anak laki-laki yang sah dalam garis laki-laki baik keturunan dari kelahiran atau keturunan karena pengangkatan. Dengan demikian, diperbolehkan mengangkat anak laki-laki sebagai anaknya.

2) Seorang janda (cerai mati) yang tidak mempunyai anak laki-laki dan tidak dilarang oleh bekas suaminya dengan suatu wasiat. (Pasal 5)

3) Yang boleh diangkat adalah anak Tionghoa laki-laki yang tidak beristri dan tidak beranak dan tidak sedang dalam status diangkat oleh orang lain. (Pasal 6)

4) Usia yang diangkat harus 18 tahun lebih muda dari suami dan 15 tahun lebih muda dari istri. (Pasal 7 ayat 1); Adopsi harus dilakukan atas kata sepakat;

5) Pengangkatan anak harus dilakukan dengan akta notaris. (Pasal 10)

6) Pengangkatan terhadap anak perempuan dan pengangkatan dengan cara tidak membuat akta otentik batal demi hukum. (Pasal 15 ayat Di

${ }^{25}$ Nur Rohim Yunus, Restorasi Budaya Hukum Masyarakat Indonesia, (Bogor: Jurisprudence Press, 2012), h. 78. 
samping itu adopsi, atas tuntutan oleh pihak yang berkepentingan juga dapat dinyatakan batal.

7) Suatu adopsi tidak dapat dibatalkan dengan kesepakatan para pihak. (Pasal 15 ayat 1). Pasal tersebut merupakan penyimpangan dari ketentuan Pasal 1338 ayat KUH Perdata (BW) yang menyatakan bahwa suatu perjanjian yang dibuat secara sah dapat dibatalkan dengan sepakat para pihak yang membuat perjanjian yang bersangkutan.

8) Secara yuridis formal, motif tidak ada ketentuannya. Akan tetapi, secara cultural motif pengangkatan anak dalam system adat Tionghoa agar dapat meneruskan keturunan, agar dapat menerima abu leluhur, dan sebagai pancingan agar dapat memperoleh keturunan laki-laki dalam BW, yaitu karena BW memandang suatu pernikahan sebagai bentuk hidup bersama, bukan untuk mengadakan keturunan. KUHPerdata Belanda yang lama tidak mengenal lembaga adopsi sehingga KUHPerdata Indonesia pun tidak mengenalnya meskipun Code Civil Perancis mengenal adopsi. Hal ini disebabkan karena pandangan orangorang Belanda yang menganggap anak hanya mereka yang berhubungan darah semata-mata. Akan tetapi, perkembangan selanjutnya adalah bahwa adopsi sudah dikenal dalam KUH Perdata Belanda yang baru yaitu sejak tahun 1956.

\section{Studi Komparatif Hukum Islam dan Hukum Perdata Barat (BW) Mengenai Kedudukan Wali Nikah bagi Anak Angkat}

Dalam KUHPerdata (BW) tidak ada aturan-aturan yang khusus mengenai wali nikah bagi anak angkat. KUH Perdata Belanda (BW) maupun KUH Perdata Indonesia hanya mengatur sistem perwalian secara umum. Walaupun terdapat perbedaan-perbedaan, untuk orang yang beragama Islam saat ini yang kita pakai sebagai undang-undang di Indonesia adalah ketentuan UU No.1 tahun 1974 tentang perkawinan dan ketentuan-ketentuan yang terdapat dalam KUH Perdata khusus dipergunakan hanya sebagai pedoman hukum bukan sebagai undangundang (asas Lex Spesialis Derogat Lex Generalis) Dalam hal ini, KUH Perdata tidak mengatur hal-hal yang berkaitan dengan wali nikah. Adapun wali nikah dijelaskan dalam pasal 19-23 Kompilasi Hukum Islam, yang menjelaskan mengenai macam-macam wali nikah, dan siapa-siapa yang berhak menjadi wali bagi calon mempelai wanita yang bertindak untuk menikahkannya serta pasal 14 UU RI No. 1 Tahun 1974 tentang Perkawinan yang mengatur bahwa wali nikah merupakan salah satu pihak yang berhak untuk mencegah terjadinya perkawinan. Setelah peneliti melakukan studi komparatif terhadap Hukum Perdata Barat dan Hukum Perdata Islam maka peneliti dapat mengetahui perbedaan yang mendasar antara kedua hukum tersebut dan mengelompokkan perbedaan tersebut ke dalam 6 bagian, yaitu: 1). Ketentuan Umur, 2). 
Pengangkatan wali, 3). Kewajiban wali terhadap diri anak, 4). Kewajiban wali terhadap harta anak, 5). Ketentuan terhadap anak yang lahir di luar perkawinan, 6). Ketentuan tentang perwalian pengawas, perwalian oleh perkumpulan, yayasan, dan lembaga sosial.

Selain dari perbedaan-perbedaan tersebut, terdapat pula perbedaan yang Istimewa yang hanya terdapat dalam hukum perdata Islam, yaitu wali nikah bagi anak angkat perempuan wajib ayah kandungnya sedangkan berdasarkan KUH Perdata Belanda (BW) wali nikah dapat ditunjuk dan diwakilkan.

Berdasarkan uraian di atas, Studi Komparatif Hukum Islam dan Hukum Perdata Barat (BW) Mengenai Kedudukan Wali Nikah bagi Anak Angkat diperoleh persamaan dan perbedaan sebagai berikut:

a. Wajib adanya Wali di dalam Pernikahan. Di dalam Al Qur'an dan Hadist terdapat ketentuan tentang adanya wali dalam suatu perkawinan. Ketentuan itu antara lain: 1) Firman Allah SWT di dalam surat An Nisa 25 "Hendaklah kamu nikahi perempuan itu dengan seizin Walinya". 2) Hadist yang diriwayatkan oleh Achmad. "Tidak sah nikah melainkan dengan wali dan dua orang saksi yang adil". 3) Hadist yang diriwayatkan oleh Hurairoh. "Tidaklah Wanita menikahkan dirinya bahwasanya wanita berzina itu adalah yang menikahkan dirinya". 4) Hadist yang diriwayatkan Bukhori / Muslim. "Barang siapa yang menikah tanpa seijin walinya, maka nikahnya batal" . Di dalam pasal 19 Kompilasi Hukum Islam menyatakan: "Wali nikah dalam perkawinan merupakan rukun yang harus dipenuhi bagi calon mempelai wanita yang bertindak untuk menikahkannya" ${ }^{26} \mathrm{Hal}$ ini sesuai dengan yang tertera dalam KUH Perdata (BW) Staatblaad 1917 No. 129 dan UU Perkawinan di Indonesia, yang menyatakan wali dalam pernikahan serta haknya dalam pembatalan pernikahan dijelaskan dalam Pasal 26 ayat (1).

b. Wali Nikah Anak Angkat Perempuan Wajib Ayah kandung dan wali nasabnya. Sebagaimana yang diceritakan Ibnu Umar: Kami tidak pernah memanggil Zaid bin Haritsah, namun Zaid bin Muhammad, sampai Allah menurunkan firmannya di surat Al-Ahzab ayat (HR. Bukhari) Berdasarkan hadits di atas, seorang anak angkat perempuan yang akan melaksanakan pernikahan, maka yang menjadi Wali Nikah adalah ayah kandungnya, dan boleh mewakilkan kepada ayah angkatnya untuk menikahkannya. Selanjutnya di dalam Kompilasi Hukum Islam (KHI) mengenai pernikahan dijelaskan dalam pasal 20-23 yang menyatakan: 1) Yang bertindak sebagai wali nikah ialah seorang laki-laki yang memenuhi syarat hukum Islam yakni muslim, akil dan baligh. 2) Wali nikah terdiri dari Wali nasab dan Wali hakim Pada pasal 21, dibahas empat kelompok wali nasab yang pembahasannya sama dengan fiqh Islam seperti pertama, kelompok kerabat laki-laki garis lurus keatas. Kedua, kelompok kerabat saudara laki-laki kandung, seayah dan keturunan laki-laki

${ }^{26}$ Kompilasi Hukum Islam. Fokus Media. 2014 
mereka. Ketiga, kelompok kerabat paman, yakni saudara laki-laki kandung ayah, saudara seayah dan keturunan laki-laki mereka. Keempat, kelompok saudara laki-laki kandung kakek, saudara laki-laki seayah kakek, dan keturunan laki-laki mereka. Sedangkan berdasarkan KUH Perdata (BW) dijelaskan dalam hal perwalian, sejak putusan diucapkan oleh pengadilan, maka orang tua angkat menjadi wali dari anak angkat tersebut. Sejak saat itu pula, segala hak dan kewajiban orang tua kandung beralih pada orang tua angkat. Kecuali bagi anak angkat perempuan beragama Islam, bila dia akan menikah maka yang bisa menjadi wali nikahnya hanyalah orangtua kandungnya atau saudara sedarahnya ${ }^{27}$. 2. Perbedaan a. Kedudukan Wali dalam Pernikahan Terdapat perbedaan signifikan mengenai pengangkatan wali. Sebagaimana dipahami pada KUH Perdata (BW) tidak mencantumkan wali sebagai rukun nikah, alasannya dengan dibuatnnya aturan-aturan pembatasan umur dan kemestian pesetujuan, keberadaan wali sebagai pihak yang menentukan menjadi tidak penting, lain halnya pada KHI posisi wali berkedudukan sangat penting dalam hal perkawinan. Menurut KUH Perdata terjadinya perwalian ini dapat diperinci sebagai berikut: 1) Perwalian oleh suami/isteri yang hidup terlama, pasal 345 sampai dengan pasal 354. 2) Perwalian yang ditunjuk oleh bapak / ibu dengan surat wasiat atau akte notaris, pasal 355 sampai dengan 358. 3) Perwalian yang diangkat oleh hakim, pasal 359 sampai pasal 364 b. Usia anak yang berhak mendapatkan perwalian Di dalam KUH Perdata Belanda (BW) Pasal 330 ayat (3) menyatakan seorang anak yang berhak menerima perwalian adalah anak-anak yang berusia di bawah 21 tahun. Hal ini tidak sesuai dengan Hukum Islam yang menyatakan wajib hukumnya adanya wali dari calon pengantin wanita yang telah baligh dan berakal sehat tanpa batasan umur.

\section{Kesimpulan}

Berdasarkan Hadits-hadits serta Kompilasi hukum Islam (KHI) wali berkedudukan sangat penting dalam hal perkawinan. Wali dalam pernikahan seorang anak angkat perempuan akan melaksanakan pernikahan adalah ayah kandungnya, dan boleh mewakilkan kepada ayah angkatnya untuk menikahkannya. Hal tersebut dapat didefinisikan yang berhak menikahkan seorang anak angkat perempuan adalah orang tua kandung dan wali nasabnya, apabila tidak ada satu pun kerabat dekatnya yang tidak mau atau tidak sempat maka dapat diwakilkan kepada orang lain sebagai wali hakim pernikahannya. KUH Perdata (BW) tidak mencantumkan wali sebagai rukun nikah, alasannya dengan dibuatnya aturan-aturan pembatasan umur dan kemestian pesetujuan, keberadaan wali sebagai pihak yang menentukan menjadi tidak penting. Di dalam KUH Perdata (BW) Pasal 330 ayat (3) dijelaskan seorang anak yang berhak

${ }_{27}$ Zaini Muderis, Adopsi, Suatu Tinjauan Dari Tiga Sistem Hukum, Jakarta: Sinar Grafika, 2015. Cetakan ke-4. h. 125. 
menerima perwalian adalah anak-anak yang berusia di bawah 21 tahun. Selain itu pula KUH Perdata (BW) menjelaskan dalam hal perwalian, sejak putusan diucapkan oleh pengadilan, maka orang tua angkat menjadi wali dari anak angkat tersebut. Sejak saat itu pula, segala hak dan kewajiban orang tua kandung beralih pada orang tua angkat. Kecuali bagi anak angkat perempuan beragama Islam, bila dia akan menikah maka yang bisa menjadi wali nikahnya hanyalah orangtua kandungnya atau saudara sedarahnya. Setelah peneliti mengadakan studi komparatif berdasarkan sumber-sumber serta literatur, maka diperoleh beberapa persamaan dan perbedaan antara lain: a. Persamaan 1) Wajib adanya Wali di dalam Pernikahan 2) Wali Nikah Anak Angkat Perempuan Wajib Ayah kandung dan wali nasabnya. b. Perbedaan 1) Hukum Islam menegaskan pentingnya kedudukan wali dalam pernikahan sementara KUH Perdata (BW) wali tidak dimasukkan dalam rukun pernikahan. 2) KUH Perdata Belanda (BW) Pasal 330 ayat (3) menyatakan seorang anak yang berhak menerima perwalian adalah anak- anak yang berusia di bawah 21 tahun sedangkan menurut Hukum Islam calon pengantin wanita yang telah baligh dan berakal sehat tanpa batasan umur wajib memiliki seorang wali dalam pernikahannya.

\section{Daftar Pustaka}

Abd. Rahman Ghazaly, Fiqih Munakahat, (Jakarta: Prenada Media Group, 2002)

Abidin, Slamet, dan Aminuddin, Fiqih Munakahat, Jilid I, Bandung: CV Pustaka Setia, 1999.

Aji, Ahmad Mukri, Urgensi maslahat mursalah dalam dialektika pemikiran hukum Islam, Bogor: Pustaka Pena Ilahi, 2012.

Basyir, Ahmad Azhar, Hukum Pernikahan Islam, Yogyakarta: UII Press, 2004.

Departemen Pendidikan dan Kebudayaan, Kamus Besar Bahasa Indonesia, Jakarta: Balai Pustaka, 2012.

Departemen Pendidikan Nasional, Kamus Besar Bahasa Indonesia, Jakarta: Balai Pustaka, 2014.

Ghazzi, Syekh Muhammad bin Qasim, Fath al-Qarib, Indonesia: Maktabah allhya at-Kutub al-Arabiah, tth. Hakim, Rahmat, Hukum Pernikahan Islam, Bandung: Pustaka Setia, 2000.

Hamid, Zahry, Pokok-Pokok Hukum Pernikahan Islam dan Undang- Undang Pernikahan di Indonesia, Yogyakarta: Bina Cipta, 1978

Hasan, Ahmad, Soal Jawab Tentang Berbagai Masalah-Masalah Agama, Bandung: PT Penerbit Diponegoro, Jilid 1-2, 2003.

Ismail, Syuhudi, Pengantar Ilmu Hadis, Bandung: Angkasa, 1994.

Jaziri, Abdurrrahman, Kitab al-Fiqh 'ala al-Mazahib al-Arba'ah, Juz IV, Beirut: Dar al-Fikr, 1972.

Kattani, al-Risalah al-Mustatrafah, Karachi: Nur Muhammad, 1960. Khalaf, Abd al-Wahhab, ‘Ilm Usul al-Fiqh, Kuwait: Dar al-Qalam, 1978.

Muchtar, Kamal, Ushul Fiqh, Jilid 1, Yogyakarta: PT Dana Bhakti Wakaf, 1995. 
Mudjib, Abdul, Kaidah-Kaidah Ilmu Fiqh (Al-Qowa'idul Fiqhiyyah), Jakarta: Kalam Mulia, t.th.

Mohd. Idris Ramulyo, Hukum Pernikahan Islam, (Jakarta: Bumi Aksara, 1996)

Munawwir, Ahmad Warson, Kamus Al-Munawwir Arab-Indonesia Terlengkap, Yogyakarta: Pustaka Progressif, 1997.

Qurthubi, al-Jami' li Ahkam al-Qur'an (Tafsir al-Qurthubi), Beirut: Dar alMa'rifah, Juz 1, t.th.

Ramulyo, Moh. Idris, Hukum Pernikahan Islam, Suatu Analisis dari UndangUndang No. 1 Tahun 1974 dan Kompilasi Hukum Islam, Jakarta: Bumi Aksara, 2002.

Rofiq, Ahmad, Hukum Islam di Indonesia, Jakarta: PT. Raja Grafindo Persada, 1977.

Rusyd, Abul Walid Muhammad Ibn Ahmad Ibn Muhammad Ibnu, Al- Faqih, Bidayat al-Mujtahid Wa nihayat al-Muqtasid, Beirut: Dar al- Jiil, juz 2, 1409H/1989M.

Sabiq Sayyid, Fiqih Sunnah, (Jakarta: Pena Pundi Aksara), 2004

Saekan dan Erniati Effendi, Sejarah Penyusunan Kompilasi Hukum Islam di Indonesia, Surabaya: Arkola, 1977.

San'ani, Muhammad bin Ismail al-Kahlani, Subul as-Salam, Juz 3, Cairo: Syirkah Maktabah Mustafa al-Babi al-Halabi, 1950.

Sarthawi, Mahmud Ali, Syarkh Qanun al-Ahwal al-Shakhshiyyah, Aman Jordania: Daar al-Fikr, 1997.

Ash-Shiddieqy, Hasbi, Sejarah dan Pengantar Ilmu Hadis, Jakarta: Bulan Bintang, 1989.

Ash-Shiddieqy, Hasbi, Koleksi Hadis-Hadis Hukum, Semarang: PT. Pustaka Rizki Putra, jilid 8, 2001

Ash-Shiddieqy, Hasbi, Mutiara Hadis, jilid 5, Semarang; PT. Pustaka Rizki Putra, 2003.

Ash-Shiddieqy, Hasbi, Pokok-Pokok Pegangan Imam Madzhab, Semarang: PT Putaka Rizki Putra, 1997

Sosroatmodjo, Arso, dan A. Wasit Aulawi, Hukum Pernikahan di Indonesia, Jakarta; Bulan Bintang, 1975.

Syafi'î, Al-Imam Abi Abdullah Muhammad bin Idris, Al-Umm, Juz. 5, Beirut: Dâr al-Kutub al-Ilmiah, tth.

Syairazi, Ibrahim ibn 'Ali Ibn Yusuf, Al-Muhadzab fi al-Fiqh al-Imam asy-Syafi'i, Juz. 2, Beirut: Daar al-Fikr, tth. Syalthut, Mahmud, Fiqih Tujuh Madzhab, terj. Abdullah Zakiy al- Kaaf, Bandung: CV Pustaka Setia, 2000.

Syarakhsi, Muhammad Ibn Abi Sahl, Al-Mabshuth, Juz. 5, Beirut: Daar alMa'rifah, 1404.

H. Syarifuddin, Amir, Hukum Pernikahan Islam di Indonesia, Jakarta: PT Bumi Aksara, 2007.

Syaukkani, Al-Alamah Ibn Ali Ibn Muhammad, Nail al -Autar Min Asyrari Muntaqa al-Akhbar, Juz 4, Beirut: Daar al-Qutub al- Arabia, tth. 
Syukur dan Ahmad Rivai Uthman, “Al-Syafi'i Biografi dan Pemikirannya Dalam Masalah Akidah, Politik dan Fiqih", Jakarta: PT Lentera Basritama, 2005

Syurbasyi, Ahmad Asy, Al-Aimmah al-Arba'ah, Terj. Futuhal Arifin, "Biografi Empat Imam Mazhab", Jakarta: Pustaka Qalami, 2003.

Tahanawi, Qawaid fi 'Ulum al-Hadis, Beirut: Maktab al-Nahdah, 1972.

Thalib, Sayuti, Hukum Kekeluargaan Indonesia, Jakarta: UI Press, Cet. 5, 1986.

Uwaidah, Syekh Kamil Muhammad, Fiqih Wanita, terj. M. Abdul Ghofar, Jakarta: Pustaka al-Kautsar, cet. 10, 2002.

Wakhid, Muhammad Abdul, Syarh Fath al-Qadir, Juz 3, Beirut: Daar al-Fikr, tth. Yayasan Penyelenggara Penterjemah/Pentafsir Al-Qur'an, Al-Qur'an dan Terjemahnya, Jakarta: Depag RI, 1986.

Yunus, Mahmud, Hukum Pernikahan dalam Islam, Jakarta: PT Hidakarya Agung, Cet. 12, 1990.

Yunus, Nur Rohim. Restorasi Budaya Hukum Masyarakat Indonesia, Bogor: Jurisprudence Press, 2012.

Zaini Muderis, Adopsi, Suatu Tinjauan Dari Tiga Sistem Hukum, Jakarta: Sinar Grafika, 2015. Cetakan ke-4

Zahrah, Abu, Tarikh al-Mazahib al-Fiqhiyah, Kairo: Mathba'ah al- Madani, t.th.

Zahrah, Abu, Hayatuhu wa Asruhu wa Fikruhu ara-Uhu wa Fiqhuhu, Terj. Abdul Zahrah, Muhammad Abu, Usul al-Fiqh, Cairo: Dar al-Fikr al'Arabi, 1958

Zein, Satria Effendi M., Ushul Fiqh, Jakarta: Prenada Media, 2005. 


\section{Mizan}

MIZAN; JURNAL ILMU SYARIAH (ISSN: 2089-032X) adalah berkala ilmiah yang diterbitkan oleh Program Studi Akhwal al Syakhsyiyyah, Fakultas Agama Islam Universitas Ibn Khaldun Bogor. Mizan; Jurnal IImu Syariah mengkhususkan diri dalam pengkajian ilmu-ilmu Syariah, Hukum Keluarga dan Studi Islam. Terbit dua kali dalam satu tahun di setiap bulan Juni dan Desember.

Redaksi menerima artikel-artikel dari para sarjana, pemerhati, dan peneliti dalam bidang IImu Syariah untuk dipublikasikan setelah proses seleksi yang ketat, telaah mitra bestari, serta proses penyuntingan secara serius. Secara substantif, setiap artikel yang dipublikasikan dalam berkala ilmiah ini merupakan pandangan dan sekaligus akan dipertanggungjawabkan secara ilmiah oleh para penulisnya.

ARTIKEL-ARTIKEL MIZAN; JURNAL ILMU SYARIAH TELAH TERINDEKS DAN ONLINE PADA:

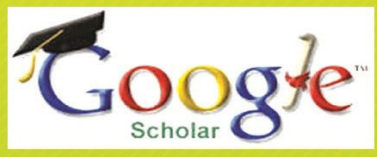

